\title{
ANALISIS FAKTOR-FAKTOR YANG MEMPENGARUHI KEBERHASILAN BERWIRAUSAHA INDUSTRI PERCETAKAN (STUDI KASUS WIRAUSAHA INDUSTRI PERCETAKAN DI KOTA JAMBI)
}

\author{
Hermansyah $^{1)}$, Dahmiri ${ }^{2)}$ \\ ${ }^{1.2)}$ Fakultas Ekonomi dan Bisnis Universitas Jambi \\ E-mail hermansyahmgt@gmail.com
}

\begin{abstract}
This study aims to determine the factors that influence the success of the Printing Industry business in Jambi City. The population in this study was the printing industry entrepreneur with 55 respondents. Sample collection was carried out by distributing questionnaires with census techniques to 55 entrepreneurs who already have a printing industry in the city of Jambi. This research uses Multiple Linear Regression analysis tools. The results showed that the factors that had a significant influence were the Marketing and Sales Factors, and Government Regulation Factors. Factors that did not have a significant effect were Opportunity Factor, Human Factor (HR), Financial Factor, Organizational Factor, Planning Factor, Business Management Factor, Administrative Factor, and Business Record Factor. And the most dominant factor is the Marketing and Sales Factor. With good marketing and large sales, business success will be even greater.
\end{abstract}

Keywords: Business Success, Printing Industry.

\section{Latar Belakang}

Kemajuan zaman yang meningkat sehingga membuat seseorang harus bersaing, seperti persaingan tingkat kesejahteraan kehidupan yang selalu ingin tinggi dan terpandang. Tetapi pada kenyataannya lapangan pekerjaan yang terbatas sehingga membuat seseorang harus menerima kenyataan yang ada walaupun sudah mempunyai pengetahuan sebelum terjun kedunia pekerjaan. Peristiwa ini justru tidak membuat penduduk di indonesia terutama kota Jambi patah semangat, tanpa kita sadari penomena ini harus didorong dengan cara pandang dan pola pikir penduduk harus mampu berpikir secara kreatif dan inovatif dalam menghadapinya sehingga mampu dan berani menyelesaikan persoalan tersebut. Salah satu solusinya adalah menjadi wirausaha. Berbagai factor yang mempengaruhi orang untuk berwirausaha antara lain adalah factor motivasi dan sikap (Revia Setiani, Dahmiri, Sigit Indrawijaya, 2019)

Perkembangan teknologi yang semakin maju membuat hampir segala aktifitas manusia berkaitan dengan teknologi salah satunya pekerjaan, kegiatan berwirausaha hampir sebagian pengusaha memanfaatkan kemajuan teknologi ini sangat berdampak baik sebagai suatu peluang baru dalam kegiatan berwirausaha dengan mengkombinasikan kreatifitas yang dimiliki dengan teknologi adalah suatu ide yang sangat baik sekali dalam pengerjaan suatu pekerjaan, seperti berbagai usaha industri hampir setiap bidang usaha sangat membutuhkan kemajuan teknologi, salah satunya industri percetakan diketahui sektor ini merupakan penopang ekonomi nasional dalam beberapa tahun terakhir industri ini berperan penting dalam membantu peningkatan perekonomian nasional hal ini sejalan dengan perkembangan teknologi digital yang sangat pesat pada era sekarang.

Pada tahun 2018 ada beberapa usaha digital yang sangat menjanjikan yaitu, percetakan kartu undangan, kartu nama, percetakan mug atau piring, percetakan barang promosional, percetakan case handphone, dan kaos sablon. Industri percetakan ini akan megalami pertumbuhan sebesar 10\% pada tahun 2019 karena seiring dengan adanya penyelengaraan pilkada pada tahun 2019 sehingga banyaknya permintaan terhadap 
percetakan alat peraga kampanye terutama untuk surat suara hal ini dapat membuktikan bahwa percetakan salah satu industri yang mendapat suatu keberkahan dari adanya penyelenggaraan pemilihan kepala daerah.

\section{Tujuan Penelitian}

1. Untuk mengetahui Pengaruh Faktor-faktor apa yang berpengaruhi positif dan signifikan terhadap Keberhasilan berwirausaha Industri Percetakan di Kota Jambi.

2. Untuk mengetahui faktor-faktor apa yang paling Dominan dalam mempengaruhi keberhasilan berwirausaha Industri Percetakan di Kota Jambi.

\section{TINJAUAN PUSTAKA}

\section{Definisi Kewirausahaan}

Menurut Suryana (2014) Kewirausahaan adalah usaha untuk menciptakan nilai tambah dengan jalan mengkombinasikan sumber-sumber melalui cara-cara baru dan berbeda utnuk memenangkan persaingan. Nilai tambah tersebut dapat diciptakan dengan cara mengembangkan teknologi dan ilmu pengetahuan, menghasilkan barang dan jasa sehingga lebih efisien, memperbaiki produk dan jasa yang sudah ada dan menemukan cara untuk memberikan kepuasaan kepada konsumen.

\section{Definisi Wirausaha}

Wirausahawan adalah mereka yang melakukan usaha-usaha kreatif dan inovatif, dengan jalan mengembangkan ide dan meramu sumber daya untuk menemukan peluang dan perbaikan hidup (Suryana, 2013). Menurut Joseph Schumpeter dalam Muchson (2017) menyatakan enterpreuner adalah seseorang yang memiliki kemampuan untuk melihat dan mengevaluasi peluang bisnis, memperoleh sumber daya yang diperlukan untuk mengambil keunggulan darinya dan berinisiatif mengambil tindakan yang tepat untuk menjamin sukses.

\section{Defenisi Keberhasilan Usaha}

Pengertian dari keberhasilan atau sukses pendapat Suryana \& Kartib, (2010) yaitu dapat diformulasikan sebagai berikut: sukses (S) adalah fungsi dari Visi (V), Motivasi (M) dan kompetensi $(\mathrm{K})$ individu dan ini suatu model secara logika adalah sebagai berikut : $\mathrm{S}=$ $\mathrm{F}(\mathrm{V}, \mathrm{M}, \mathrm{K})$, dan secara matematisnya adalah $\mathrm{S}=\mathrm{V}+\mathrm{M}+\mathrm{K}$. Artinya, tercapainya suatu keberhasilan sangat tergantung pada visi, motivasi, kompetensi setiap individu.

Apabila seseorang tidak tercapai suatu kesuksesan, kemungkinan disebabkan visinya terlalu tinggi, sedangkan kompetensinya rendah walau motivasinya cukup tinggi. Sebenarnya komponen tersebut saling berkaitan dan saling mendukung satu sama lain.

\section{Faktor-faktor Keberhasilan Berwirausaha}

Menurut Suryana, (2013) keberhasilan dalam kewirausahaan ditentukan oleh tiga faktor, yaitu yang mencakup hal-hal berikut.

1. Kemampuan dan Kemauan. Orang yang tidak memiliki kemampuan, tetapi banyak kemauan dan orang yang memiki kemauan, tetapi tidak memiliki kemampuan, keduanya tidak akan menjadi wirausahawan yang sukses. Sebaliknya memiliki kemauan dan dilengkapi dengan kemampuan akan menjadi orang yang sukses. Kemauan saja tidak cukup bila tidak dilengkapi dengan kemampuan.

2. Tekad yang kuat dan Kerja keras. Orang yang tidak memiliki tekad yang kuat, tetapi memiliki kemauan untuk bekerja keras dan orang yang suka bekerja keras, tetapi tidak memiliki tekad yang kuat, keduanya tidak akan menjadi wirausahawan yang sukses.

3. Kesempatan dan Peluang. Ada solusi ada peluang, sebaliknya tidak ada solusi tidak akan ada peluang. Peluang ada jika kita menciptakan peluang sendiri, bukan mencaricari atau menunggu peluang yang datang kepada kita. 
Menurut Hendro, (2011) mengatakan bahwa faktor-faktor keberhasilan usaha yaitu:

a. Faktor peluang

Banyak peluang emas tapi belum tentu tepat untuk seorang wirausaha, karena peluang yang tepat mengandung keserasian, dan keharmonisan antara bisnis yang dijalankan, kondisi, situasi, keadaan pasar, sehingga dapat dikatahui peluang tersebut. Peluang emas seringkali hanya berjangka waktu pendek atau hanya sekedar momentum. Hal ini yang membuat bisnis hanya mempunyai usia singkat karena peluang emas yang bersifat momentum saja. Peluang yang tepat dan berhasil adalah peluang yang bersakala industry dan bisa tumbuh besar.

b. Faktor Manusia (SDM)

Terdapat 5 faktor yang menjadi kesuksesan dalam operasional yaitu, 1) SDM yang berkualitas, hal ini penting karena SDM atau manusia yang merencanakan, strategic planner. 2) Melakukan pelaksanaan yang sesuai dan tepat dengan perencanaan serta kreatif dalam mengatasi masalah dan itu membutuhkan SDM yang handal sebagai manger hebat. 3) Mengawasi suatu pekerjaan sesuai dengan perencanaan dan target yang dibutuhkan. Cntroller yang hebat mencakup quality control, financial control, serta supervisor. 4) Mengembangkan suatu usaha membutuhkan orang yang hebat dalam memasarkan dan menjual, yaitu marketer dan reseller. 5) Faktor kepemimpinan atau leadership. Jika tidak ada leader, maka tidak ada pengikut, begitu sebaliknya. Faktor SDM menjadi sangat penting. Tidak ada nada kesuksesan bila tidak mempunyai pemimpin yang hebat.

c. Faktor Keuangan

Arus kas yang paling penting, sebab, bila arus khas tidak mengalir maka bisnis akan berhenti dan mati. Faktor biaya juga sangat penting dalam kelangsungan usaha contohnya: 1) Pengendalian biaya dan anggaran. 2) Pencairan dan modal kerja, dana investasi, dan dana lainnya. 3) Perencanaan dan penetapan harga produk biaya princian rudi, laba, dan sebagainya.

d. Faktor Organisasi

Organisasi usaha mempunyai sifat tidak statis dinamis, kreatif, dan berwawasan kedepan. Adapun hal-hal yang harus dilakukan sebagai karyawan, meliputi: 1) Jenis pekerjaan yang dilakukan. 2) Batasan uraian tugas. 3) Hubungan pekerjaan dan temantemannya. 4) Batasan yang jelas antara pekerjaan yang satu dengan pekerjaan yang lain. 5) Terjadinya hubunan yang berkesinambungan dan kedekatan satu dengan yang lain.

e. Faktor perencanaan

Bekerja tanpa adanya tencana seperti berjalan tanpa adanya tujuan. Sehingga faktor perencanaan merupakan faktor penting, contohnya ialaha: 1) Perencanaan visi, mis, strategi jangka panjang, dan strategi jangka pendek. 2) perencanaan operasional dan program pemasaran. 3) Perencanaan produk. 4) perencanaan informasi teknologi. 5) perencanaan pendistribusian produk. 6) perencaan jumlah produk yang akan dijual.

f. Faktor Pengeloaan Usaha

Keberhasilan dalam usaha juga dibutuhkan dalam hal tindakan, maka faktor pengelolaan usaha merupakan hal penting, diantaranya meliputi: 1) Menusun organisasi. 2) Mengelola SDM 3) Mengelola aset. 4) membuat jadwal usaha dan kegiatan. 5) menetapkan jumlah tenaga kerja. 6) mengatur distribusi barang. 7) mengendalikan persedian barang 8) mengendalikan suatu mutu produk.

g. Faktor Pemasaran dan Penjualan

Penjualan dan pemasaran mempunyai peran penting bagi kelancaran usaha, karena penjualan merupakan dasar dari kemampuan kewirausahaan.

h. Faktor Adminitrasi 
Tanpa pencatatan dan dokumentasi yang baik dan pengumpulan serta pengelolaan data adminitrasi, maka strategi, taktik, perencaan, pengembangan, program-program, dan arah perusahaan menjadi tidak berjalan sesuai harapan karena hanya dilakukan berdasarkan feeling atau perasaan. Hal ini berbahaya dan akan menjadi penghalang bagi kesuksesan berwirausaha.

i. Faktor Peraturan Pemerintah

Faktor peraturan pemerintah, politik, ekonomi, dan budaya lokal. Faktor ini berpengaruh banyak karena usaha juga berhubungan dengan: 1) Peraturan pemerintah, 2) Legalitas perizinan, 3) situasi ekonomi dan politik, 4) perkembangan budaya lokal, 5)Lingkungan sosial yang berbeda setiap daerah.

j. Catatan Bisnis

Banyak usaha yang sulit dan tidak berkembang hanya disebabkan pengusaha tidak tahu sejauh mana bisnisnya berjalan. Catatan bisnis membantu untuk mengetahui sejauh mana usha berjalan. contohnya, catatan keuangan, catatan SDM dan personalia, catatan Pemasaran,, serta catatan produksi.

\section{Kerangka Pemikiran}

Faktor-faktor Yang Mempengaruhi(X):

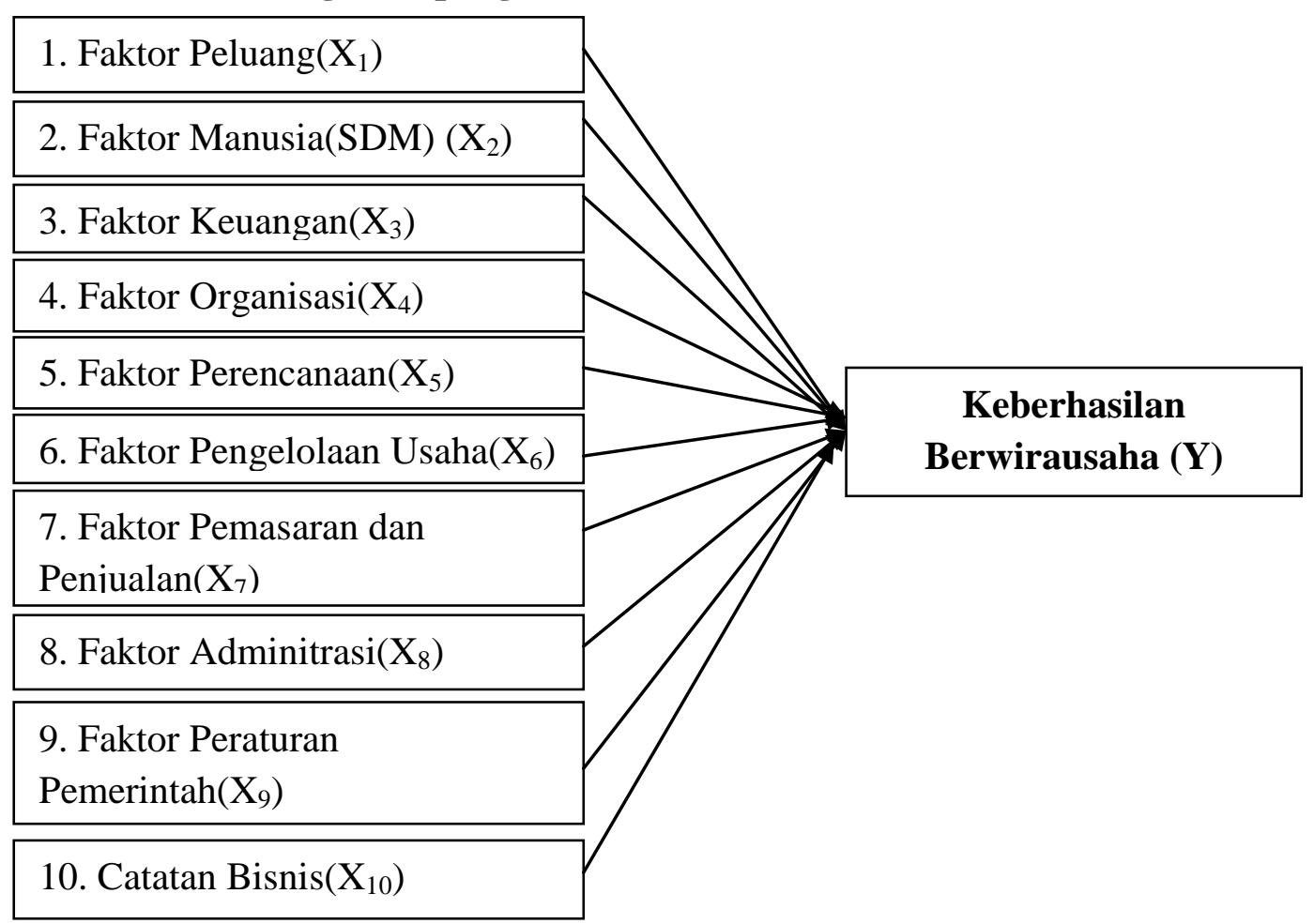

\section{Hipotesis}

H0 :Tidak terdapat pengaruh faktor-faktor keberhasilan usaha pada usaha industri percetakan di Kota Jambi baik secara simultan maupun parsial.

H1 :Terdapat pengaruh faktor-faktor keberhasilan berwirausaha industri percetakan di Kota Jambi baik secara simultan maupun parsial.

\section{METODE PENELITIAN}

\section{Jenis dan Sumber Data}

Teknik pengumpulan data merupakan langkah yang paling utama dalam penelitian, karena tujuan dari penelitian adalah mendapatkan data. Tanpa mengetahui teknik 
pengumpulan data, maka peneliti tidak akan mendapatkan data yang memenuhi standar data yang ditetapkan. (Sugiyono,2012)

\section{Populasi}

Menurut Sugiyono, (2012) populasi adalah wilayah generalisasi yang terdiri atas: Obyek/Subjek yang mempunyai kualitas dan karakteristik tertentu yang ditetapkan oleh peneliti untuk dipelajari dan kemudian di tarik kesimpulannya. Populasi dalam penelitian ini adalah wirausaha industri percetakan di Kota Jambi yang masih aktif pada tahun 2018.

\section{Sampel}

Menurut Sugiyono, (2014) sampel adalah bagian dari jumlah dan karakteristik yang dimiliki oleh populasi tersebut. Bila populasi besar dan peneliti tidak mungkin mempelajari semua yang ada pada populasi, misalnya keterbatasan dana, tenaga dan waktu maka peneliti dapat menggunakan sampel yang diambil dari populasiitu. Untuk itu sampel yang diambil harus benar-benar representatif (mewakili).

Teknik sampling yang digunakan dalam penelitian ini adalah Probability sampling, probability sampling adalah teknik pengambilan sampel yang memberikan peluang yang sama bagi setiap unsur (anggota) populasi untuk dipilih menjadi anggota sampel caranya yaitu dengan Simple Random Sampling, dikatakan simple (sederhana) karena pengambilan anggota sampel dari populasi dilakukan secara acak tanpa memperhatikan strata yang ada dalam populasi itu.

\section{HASIL DAN PEMBAHASAN PENELITIAN \\ Uji Validitas}

Pada penelitian ini banyaknya sampel sebesar $(\mathrm{n})=55$ dan besarnya df dapat dihitung 55-2=53, dengan $\mathrm{df}=53$ dan alpha 0,05 di dapat $\mathrm{r}$ tabel $=0,2656 . \mathrm{r}$ hitung lebih besar dari $r$ tabel dan nilai positif, maka butir atau pernyataan yang ditanyakan tersebut dinyatakan valid (Ghozali, 2013). dari tabel diatas terlihat bahwa keseluruhan variabel penelitian dinyatakan valid karena $r$ hitung yang dapat dilihat dari hasil statistic Corrected Item-Total Correlation lebih besar dari $r$ tabel ( $r$ hitung $>r$ tabel).

\section{Uji Reliabilitas}

Berdasarkan hasil uji reliabilitas yang dilakukan dengan menggunakan program SPSS statistik versi 25. dapat disimpulkan bahwa keseluruhan indikator semua variabel penelitian dinyatakan reliable. Hal tersebut tergambar pada tabel 5.6. Hasil Uji Reliabilitas, keseluruhan indikator memiliki nilai cronbach alpha 0,951 >0,60

\section{Alat Analisis Data}

Metode analisis data dalam penelitian ini menggunakan analisis regredi linear berganda dan menggunakan Uji Hipotesis yaitu Uji F(simultan), uji t (parsial), dan uji koefisien determinasi.

\section{Pembahasan}

Hasil penelitian ini menunjukkan bahwa terdapat pengaruh positif dan tidak signifikan antara peluang terhadap keberhasilan usaha. Hasil ini dapat diterima berdasarkan hasil pengujian signifikansi parameter individual (uji statistik t) dapat di tampilkan bahwa nilai signifikasi t lebih kecil dari a $(0,05)$. Hasil perhitungan tersebut menyatakan bahwa peluang berpengaruh positif dan tidak signifikan terhadap keberhasilan usaha dengan $t_{\text {hitung }}<t_{\text {tabel }}(0,655<1,674)$ dan nilai signifikan yang lebih besar dari nilai probabilitas $(0,516>0,05)$.

Hasil penelitian ini menunjukkan bahwa terdapat pengaruh negatif dan tidak signifikan antara manusia(SDM) terhadap keberhasilan usaha. Hasil ini tidak dapat diterima berdasarkan hasil pengujian signifikansi parameter individual (uji statistik t) dapat 
ditampilkan bahwa nilai signifikasi t lebih besar dari a $(0,05)$. Hasil perhitumgan tersebut menyatakan bahwa manusia(SDM) berpengaruh negatif dan tidak signifikan terhadap keberhasilan usaha dengan $t_{\text {hitung }}<t_{\text {tabel }}(1,214<1,674)$ dan nilai signifikan yang lebih besar dari nilai probabilitas $(0,231>0,05)$.

Hasil penelitian ini menunjukkan bahwa terdapat pengaruh negatif dan tidak signifikan antara keuangan terhadap keberhasilan usaha. Hasil ini tidak dapat diterima berdasarkan hasil pengujian signifikansi parameter individual (uji statistik t) dapat ditampilkan bahwa nilai signifikansi t lebih besar dari a $(0,05)$. Hasil perhitungan tersebut menyatakan bahwa keuangan berpengaruh negatif dan tidak signifikan terhadap keberhasilan usaha dengan $t_{\text {hitung }}<t_{\text {tabel }}(-0,484<1,674)$ dan nilai signifikan yang lebih besar dari nilai probanilitas $(0,631>0,05)$.

Hasil penelitian ini menunjukkan bahwa terdapat pengaruh negatif dan tidak signifikan antara organisasi terhadap keberhasilan usaha. Hasil ini tidak dapat diterima berdasarkan hasil pengujian signifikansi parameter (uji statistik t) dapat ditampilkan bahwa nilai signifikansi t lebih besar a $(0,05)$. Hasil perhitungan tersebut menyatakan bahwa organisasi berpengaruh negatif dan tidak signifikan terhadap keberhasilan usaha dengan $t_{\text {hitung }}<t_{\text {tabel }}(-0,096<1,674)$.

Hasil penelitian ini menunjukkan bahwa terdapat pengaruh positif dan tidak signifikan antara perencanaan terhadap keberhasilan usaha. Hasil ini dapat diterima berdasarkan hasil pengujian signifikansi parameter individual (uji statistik t) dapat ditampilkan bahwa nilai signifakansi t lebih besar dari a $(0,05)$.

Hasil penelitian ini menunjukkan bahwa terdapat pengaruh negatif dan tidak signifikan antara pengelolaan usaha terhadap keberhasilan usaha. Hasil ini tidak dapat diterima berdasarkan hasil pengujian signifikansi parameter individual (uji statistik t) dapat ditampilkan bahwa nilai signifikansi t lebih besar dari a $(0,05)$. Hasil perhitungan tersebut menyatakan bahwa pengelolaan usaha berpengaruh negatif dan tidak signifikan terhadap keberhasilan usaha dengan $t_{\text {hitung }}<t_{\text {tabel }}(-0,884<1,674)$ dan nilai signifikan yang lebih besar dari nilai probabilitas $(0,381>0,05)$.

Hasil penelitian ini menunjukkan bahwa terdapat pengaruh positif dan signifikan antara pemasaran dan penjualan terhadap keberhasilan usaha. Hasil ini dapat diterima berdasarkan hasil pengujian signifikansi parameter individual (uji statistik t) dapat ditampilkan bahwa nilai signifikansi t lebih kecil dari a $(0,05)$. Hasil perhitungan tersebut menyatakan bahwa pemasaran dan penjualan berpengaruh positif dan signifikan terhadap keberhasilan usaha dengan $t_{\text {hitung }}>t_{\text {tabel }}(3,700>1,674)$ dan nilai signifikan yang lebih kecil dari nilai probabilitas $(0,001<0,05)$.

Hasil penelitian ini menunjukkan bahwa terdapat pengaruh positif dan tidak signifikan antara adminitrasi terhadap keberhasilan usaha. Hasil ini dapat diterima berdasarkan hasil pengujian signifikansi parameter individual (uji statistik t) dapat ditampilkan bahwa nilai signifikansi t lebih besar dari a $(0,05)$. Hasil perhitungan tersebut menyatakan bahwa adminitrasi berpengaruh negatif dan tidak signifikan terhadap keberhasilan usaha dengan $t_{\text {hitung }}<t_{\text {tabel }}(0,959<1,674)$ dan nilai signifikan yang lebih besar dari nilai probabilitas $(0,343>0,05)$.

Hasil penelitian ini menunjukkan bahwa terdapat pengaruh positif dan signifikan antara peraturan pemerintah terhadap keberhasilan usaha. Hasil ini dapat diterima berdasarkan hasil pengujian signifikansi parameter individual (uji statistik $t$ ) dapat ditampilkan bahwa nilai signifikansi t lebih kecil dari a $(0,05)$. Hasil perhitungan tersebut menyatakan bahwa peraturan pemerintah berpengaruh positif dan signifikan terhdap keberhasilan usaha dengan $t_{\text {hitung }}>t_{\text {tabel }}(2,599>1,674)$ dan nilai signifikan yenga lebih kecil dari nilai probabilitas $(0,013<0,050)$. 
Hasil penelitian ini menunjukkan bahwa terdapat pengaruh positif dan tidak signifikan antara catatan bisnis terhadap keberhasilan usaha. Hasil ini dapat diterima berdasarkan hasil pengujian signifikasi parameter individual (uji statistik t) dapat ditampilkan bahwa nilai signifikansi t lebih besar dari a $(0,05)$. Hasil perhitungan tersebut menyatakan bahwa catatan bisnis berpengaruh negatif dan tidak signifikan terhadap keberhasilan usaha dengan $t_{\text {hitung }}<t_{\text {tabel }}(0,740<1,674)$ dan nilai signifikan yang lebih besar dari nilai probabilitas $(0,463>0,05)$.

Variabel Pemasaran dan Penjualan Berpengaruh Paling Dominan Terhadap Keberhasilan Usaha.

\section{KESIMPULAN}

1. Variabel Peluang (X1) tidak berpengaruh signifikan terhadap Keberhasilan Usaha, Variabel Manusia(SDM) (X2) tidak berpengaruh signifikan terhadap Keberhasilan Usaha, Variabel Keuangan (X3) tidak berpengaruh signifikan terhadap Keberhasilan Usaha, Variabel Organisasi (X4) tidak berpengaruh signifikan terhadap Keberhasilan Usaha, Variabel Perencanaan (X5) tidak berpengaruh signifikan terhadap Keberhasilan Usaha, Variabel Pengelolaan Usaha (X6) tidak berpengaruh signifikan terhadap Keberhasilan Usaha, Variabel Pemasaran dan Penjualan (X7) berpengaruh signifikan terhadap Keberhasilan Usaha, Variabel Adminitras (X8) tidak berpengaruh signifikan terhadap Keberhasilan Usaha, Variabel Peraturan Pemerintah (X9) berpengaruh signifikan terhadap Keberhasilan Usaha, Variabel Catatn Bisnis (X10) tidak berpengaruh signifikan terhadap Keberhasilan Usaha.

2. Variabel Pemasaran dan Penjualan (X7) berpengaruh dominan terhadap Keberhasilan Usaha. Nilai signifikan lebih kecil dari probabilitas dan nilai Standardizet Coefficient Beta lebih besar dibandingkan lainnya. Hal ini menunjukkan Pemasran dan Penjualan berpengaruh signifikan terhadap Keberhasilan Usaha Industri Percetakan di Kota Jambi.

\section{DAFTAR PUSTAKA}

Alifuddin, M,. \& Razak Mashur. 2015. Kewirausahaan Strategi Membangun Kerajaan Bisnis. Jakarta: MAGNAscript Publishing.

Arikunto, S. 2010. Prosedur Penelitian Suatu Pendekatan Praktik. Jakarta: PT Rineka Cipta.

Basrowi. 2011. Kewirausahaan untuk Perguruan Tinggi. Bogor: Ghalia Indonesia

Daryanto, \& Aris. D. C. 2013. Kewirausahaan (Penanaman Jiwa Kewirausahaan). Yogyakarta. Penerbit Gava Media

Ghozali, Imam. 2011. AplikasiAnalisis Multivariate Dengan Program IBM SPSS. Badan Penerbit Universitas Diponegorom : Semarang

Hendro. 2011. Dasar-Dasar Kewirausahaan. Jakarta : Erlangga

Irawan, A., \& Mulyadi, H. (2016). Pengaruh Keterampilan Wirausaha Terhadap Keberhasilan (Studi Kasus pada Distro Anggota Kreative Independent Clothing Kommunity USAHA di Kota Bandung). Journal of Business Management Education, 1(1), 216-226.

Kasmir. 2014. Kewirausahaan. Jakarta: PT Raja Grafindo Persada

Revia Setiani, Dahmiri, Sigit Indrawijaya.(2019). Pengaruh Motivasi Dan Sikap Wirausaha Terhadap Keputusan Berwirausaha Wanita Di Kota Jambi. Jurnal Manajemen Terapan dan Keuangan Vo. 8 (1), 46-58. 